\title{
Autostimulation of Dihydrostreptomycin Uptake in Bacillus subtilis
}

\author{
By FRANZ EMLING AND JOACHIM-VOLKER HÖLTJE*† \\ Institut für Biologie II, Lehrstuhl Mikrobiologie I, Universität Tübingen, 7400 Tübingen, FRG
}

(Received 6 July 1987)

\begin{abstract}
In Bacillus subtilis it was shown that the membrane potential $(\Delta \psi)$ has to reach a threshold value of -180 to $-190 \mathrm{mV}$ for efficient uptake of dihydrostreptomycin to occur. The magnitude of $\Delta \psi$ is raised above this threshold, and dihydrostreptomycin uptake greatly enhanced, not only by dihydrostreptomycin itself (autostimulation) and by other miscoding aminoglycoside antibiotics, but also by puromycin, bacitracin and $N, N^{\prime}$-dicyclohexylcarbodiimide. Stimulation of uptake by dihydrostreptomycin or puromycin was dependent on a specific interference with ongoing protein synthesis. Thus, chloramphenicol prevented the stimulating effect of puromycin by lowering the magnitude of $\Delta \psi$. Although normally severely antagonizing streptomycin accumulation, $\mathrm{K}^{+}$, as well as spermidine and putrescine, which are known to stabilize ribosomes, consequently enhanced autostimulation of dihydrostreptomycin uptake in a $\mathrm{K}^{+}$-retention mutant with impaired protein synthesis. It is suggested that miscoding aminoglycosides and puromycin both enhance dihydrostreptomycin uptake by increasing $\Delta \psi$ due to ion fluxes, which are themselves caused by a dramatic stimulation of intracellular proteolysis of faulty proteins.
\end{abstract}

\section{INTRODUCTION}

Efficient killing of bacteria by streptomycin correlates well with the rate of its accumulation inside the cell (Hancock, 1962; Bryan et al., 1976, 1979; Taber \& Halfenger, 1976; Miller et al., 1980 ; Eisenberg et al., 1984). The factors which determine the uptake of streptomycin are thus of particular importance for its therapeutic efficiency.

In many aerobic bacterial strains $\left[{ }^{3} \mathrm{H}\right]$ dihydrostreptomycin uptake is autostimulated resulting in a biphasic uptake process (Anand et al., 1960; Hurwitz \& Rosano, 1962; Bryan \& Van den Elzen, 1976). An early energy-dependent phase (EDPI) with a low rate of uptake is followed by a second greatly enhanced energy-dependent phase (EDPII) of uptake (Bryan \& Van den Elzen, 1977). Self-enhancement of dihydrostreptomycin accumulation, a prerequisite for its antibacterial action (Hancock, 1981), has been suggested to depend on codon-misreading during protein synthesis (Hurwitz \& Rosano, 1962; Höltje, 1978; Davis et al., 1986). With Escherichia coli it has been shown that preincubation with streptomycin not only increases dihydrostreptomycin accumulation but also the uptake of the polyamines putrescine and spermidine (Höltje, 1978). However, the molecular basis that triggers streptomycin uptake with increased rate (EDPII) remains obscure.

A recent model proposes the creation of membrane channels by misread proteins to be responsible for the increase in uptake (Davis et al., 1986). While the model indeed can account for a number of previously unexplained observations it fails to explain convincingly the energy

† Present address: Max-Planck-Institut für Entwicklungsbiologie, Spemannstrasse 35/II, 7400 Tübingen, FRG.

Abbreviations: CCCP, carbonyl cyanide m-chlorophenylhydrazone; DCCD, $N, N$ '-dicyclohexylcarbodiimide; $\mathrm{TPMP}^{+}$, triphenylmethylphosphonium ion; EDPI, EDPII, energy-dependent phases I and II; $\Delta \psi$, transmembrane potential difference ('membrane potential'); $\Delta \mathrm{pH}$, transmembrane $\mathrm{pH}$ difference; $\Delta p$, transmembrane proton electrochemical difference ('protonmotive force'). 
dependence of uptake as well as the specificity of stimulated uptake. Furthermore, it cannot explain a number of findings described in the present communication.

It is now well established that the uptake of dihydrostreptomycin and other aminoglycoside antibiotics into bacteria is energized by the electrical component $(\Delta \psi)$ (interior of cell negative) rather than the chemical component $(\Delta \mathrm{pH})$ of the proton electrochemical difference $(\Delta p)$ across the cytoplasmic membrane (Damper \& Epstein, 1981; Mates et al., 1982; Bryan \& Kwan, 1983; Eisenberg et al., 1984; Arrow \& Taber, 1986). It was, therefore, of interest to follow the membrane potential during the course of self-enhancement of dihydrostreptomycin accumulation. The method most used to estimate $\Delta \psi$ determines the partition of a permeable lipophilic cation, like tetraphenylmethylphosphonium (TPMP ${ }^{+}$), inside and outside the cell. Being a trivalent cation dihydrostreptomycin interferes with this technique, which therefore cannot be used in this case.

Interestingly, among the many protein synthesis inhibitors besides aminoglycosides causing misreading, only puromycin also stimulates streptomycin uptake. The mechanism of puromycin-induced enhancement of uptake may be considered an analogous situation to the autostimulation phenomenon since both antibiotics cause ribosomes to synthesize nonfunctional proteins. Therefore, an attempt was made to follow $\Delta \psi$ during puromycin-stimulated dihydrostreptomycin uptake. Based on the experimental results a model was developed proposing a common basis for the mechanism of autostimulation and puromycin-enhanced dihydrostreptomycin uptake.

\section{METHODS}

Bacterial strains and growth conditions. All strains were grown routinely in $1 \%$ Tryptone broth (Bacto, Difco) with shaking at $37^{\circ} \mathrm{C}$. This medium contained approximately $11.5 \mathrm{mM}-\mathrm{Na}^{+}, 0.8 \mathrm{mM}-\mathrm{K}^{+}$and $0.19 \mathrm{mM}-\mathrm{Mg}^{2+}$. Bacillus subtilis 60015 (trpC metC) was a gift from Dr E. Freese (NIMH, NIH, Bethesda, Md., USA). The $\mathrm{K}^{+-}$ retention mutant $168 \mathrm{KL}$ was kindly provided by $\mathrm{Dr} \mathrm{K}$. Willecke (Westdeutsches Tumorzentrum, Essen, FRG) and the ribnsomally streptomycin-resistant strain SRB15 (trpC lys3 metB strA) was obtained from Dr G. H. Chambliss (University of Wisconsin, Madison, Wis., USA).

Uptake experiments. Uptake measurements were started by adding appropriate concentrations of the respective radioactive solute ([ $\left.{ }^{3} \mathrm{H}\right)$ dihydrostreptomycin, $6.6 \mu \mathrm{M} ; 37 \mathrm{kBq} \mathrm{ml}^{-1}$; or $\left[{ }^{14} \mathrm{C}\right]$ spermidine, $\left.6.6 \mu \mathrm{M} ; 4.625 \mathrm{kBq} \mathrm{ml}^{-1}\right)$ to cells growing in the mid-exponential phase of growth at an $\mathrm{OD}_{578}$ of about 0.2 . At the indicated times $0.5 \mathrm{ml}$ samples were withdrawn and collected by filtration through cellulose nitrate membranes (pore size $0.45 \mu \mathrm{m}$; Sartorius) which had been pre-soaked in $0.1 \mathrm{M}-\mathrm{LiCl}$. The filters were immediately rinsed twice with $3 \mathrm{ml} 0.1 \mathrm{M}$ $\mathrm{LiCl}$. placed into scintillation vials and dried at $70^{\circ} \mathrm{C}$ for $30 \mathrm{~min}$. After the addition of $5 \mathrm{ml}$ scintillation fluid (Quickscint 401; W. Zinsser) the radioactivity was determined in a liquid scintillation counter (mark II; Nuclear Chicago Corp.). The results were corrected for adsorption of radioactive material to membrane filters, nonspecific binding to the bacterial cell surface and uptake by passive diffusion. For this, controls were prepared either lacking cells or with cells pre-treated with carbonyl cyanide $m$-chlorophenylhydrazone (CCCP). Further control samples were quickly cooled to $4{ }^{\circ} \mathrm{C}$ before the addition of the respective solute. Growth of the cells throughout the uptake experiment was monitored and the results were corrected for changes in the optical density of the culture. The relationship between $\mathrm{OD}_{578}$ and cell titre was determined using the viable count method; dry weight and intracellular water space were calculated on the basis of the values published by Shioi et al. (1980).

Measurement of $\Delta \psi$. This was done by measuring the distribution of the lipophilic cation $\left[{ }^{4} \mathrm{C}\right] \mathrm{TPMP}{ }^{+}$at a final concentration of $8.4 \mu \mathrm{M}\left(1.48 \mathrm{kBq} \mathrm{ml}^{-1}\right)$ as described by Shioi et al. (1980). The lipophilic anion tetraphenylboron was added to the cell suspension at a final concentration of $2 \mu \mathrm{M} 0.5 \mathrm{~min}$ before $\mathrm{TPMP}^{+}$addition to enhance TPMP $^{+}$uptake. Because TPMP ${ }^{+}$adsorbs strongly to celluiose nitrate, in these experiments cellulose acetate membrane filters (pore size $0.45 \mu \mathrm{M}$; Schleicher and Schüll) were used. The filters were pre-soaked with $8.4 \mu \mathrm{M}$ unlabelled $\mathrm{TPMP}^{+}$in $0.1 \mathrm{M}-\mathrm{LiCl}$ solution. After collection of the cells on the filters they were rinsed twice with $3 \mathrm{ml} 0.1 \mathrm{M}-\mathrm{LiCl}$ containing $8.4 \mu \mathrm{M}$ unlabelled TPMP+. $\Delta \psi$ was calculated from the Nernst equation: $\Delta \psi=(2.3 \boldsymbol{R} T / F) \log \left(\left[\mathrm{TPMP}^{+}\right]_{\text {out }} /\left[\mathrm{TPMP}^{+}\right]_{\mathrm{in}}\right)$. At $37^{\circ} \mathrm{C}$, the value of $2.3 \boldsymbol{R} T / F$ is about $61.25 \mathrm{mV}$. TPMP ${ }^{+}$uptake was usually complete in less than $1 \mathrm{~min}$ and remained constant for about 1 to $6 \mathrm{~min}$. The mean of the values measured within that time range (normally three values per individual experiment) was taken to calculate the momentary $\Delta \psi$ of the cells at zero time, i.e. the addition of $\left[{ }^{3} \mathrm{H}\right] \mathrm{TPMP}{ }^{+}$to the cell suspension. The results were corrected for adsorption of TPMP+ to the filters. Controls for non-specific binding of TPMP' to the cells were done as stated for dihydrostreptomycin uptake measurements but with toluenized cells. This procedure showed that there was no substantial non-specific binding of $\mathrm{TPMP}^{+}$to the cells. 


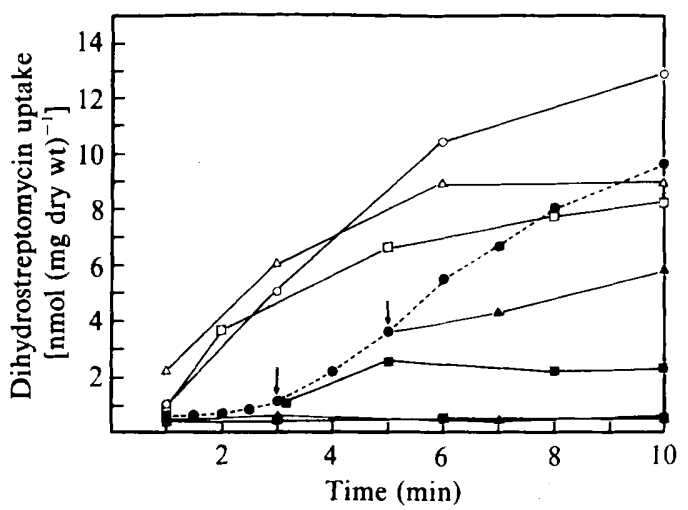

Fig. 1. Effect of various inhibitors on the uptake of dihydrostreptomycin by $B$. subtilis 60015 . Cells were grown in complex medium at $37^{\circ} \mathrm{C}$ to an $\mathrm{OD}_{578}$ of about 0.2 and pre-incubated for 3 min in the presence of $10 \mu \mathrm{g}$ actinomycin $\mathrm{ml}^{-1}(\Delta), 10 \mu \mathrm{g}$ bacitracin $\mathrm{ml}^{-1}(\mathrm{O}), 10 \mu \mathrm{g} \mathrm{DCCD} \mathrm{\textrm {ml } ^ { - 1 }}(\triangle), 8 \mu \mathrm{g}$ puromycin $\mathrm{ml}^{-1}(\square)$ or for $5 \mathrm{~min}$ in the presence of $100 \mu \mathrm{g}$ chloramphenicol ml $\mathrm{m}^{-1}(\square)$. One culture received no inhibitor and served as a control $(O) .\left[{ }^{3} \mathrm{H}\right]$ Dihydrostreptomycin was added at time zero to give a final concentration of $5 \mu \mathrm{g} \mathrm{ml}^{-1}\left(37 \mathrm{kBq} \mathrm{ml}^{-1}\right)$; samples were withdrawn at the indicated times and accumulation of dihydrostreptomycin was determined as described in Methods. The arrows indicate the times of inhibitor addition after initiation of dihydrostreptomycin uptake.

Chemicals. $\left[{ }^{3} \mathrm{H}\right] \mathrm{Dihydrostreptomycin}\left(66.6 \mathrm{GBq} \mathrm{mmol}{ }^{-1} ; 37 \mathrm{MBq} \mathrm{ml}^{-1}\right) ;\left[{ }^{14} \mathrm{C}\right]$ spermidine $\left(740 \mathrm{MBq} \mathrm{mmol}^{-1}\right.$; $\left.1.85 \mathrm{MBq} \mathrm{ml}^{-1}\right)$ and $\left[{ }^{14} \mathrm{CJTPMP}\right.$ iodide $\left(177.6 \mathrm{MBq} \mathrm{mmol}^{-1} ; 3.7 \mathrm{MBq} \mathrm{ml}^{-1}\right)$ were obtained from Amersham. Puromyin, bacitracin, actinomycin, chloramphenicol, streptomycin, kanamycin and gentamicin were purchased from Serva. Tetraphenylboron and DCCD were bought from Sigma and putrescine, spermidine and valinomycin from Calbiochem. All other chemicals used were reagent grade and obtained from various commercial sources.

\section{RESULTS}

Correlation between dihydrostreptomycin uptake and the magnitude of $\Delta \psi$

Inhibiting or stimulating effects of various antimetabolites on the rate of uptake of dihydrostreptomycin were found to correlate well with changes in $\Delta \psi$. Cells in the exponential phase of growth were either pre-incubated with the effectors before the addition of $\left[{ }^{3} \mathrm{H}\right]$ dihydrostreptomycin or the agents were added after the onset of dihydrostreptomycin uptake. As shown in Fig. 1 pre-incubation with bacitracin, DCCD and puromycin resulted in a pronounced enhancement of dihydrostreptomycin uptake as well as an increase in the magnitude of $\Delta \psi$ (Table 1). The peculiar biphasic character of uptake was abolished in the stimulated uptake curves, that is no further autostimulation was observed. The EDPI phase of uptake seemed to be skipped and dihydrostreptomycin accumulation occurred from the very beginning at a rate characteristic of the EDPII phase of uptake. In contrast to these agents, chloramphenicol and actinomycin impaired dihydrostreptomycin uptake and decreased $(-\Delta \psi)$, as compared with the control, when added to cells taking up dihydrostreptomycin or when added before $\left[{ }^{3} \mathrm{H}\right]$ dihydrostreptomycin (Fig. 1 ; Table 1).

From these measurements it can be concluded that wild-type B. subtilis 60015 cells, which during the exponential phase of growth have a standard $\Delta \psi$ of $-168 \mathrm{mV}$ when grown in Tryptone broth at $37^{\circ} \mathrm{C}$, seem to have to exceed a certain threshold of $\Delta \psi$ (about -180 to $-190 \mathrm{mV}$ ) to be able to take up dihydrostreptomycin at the rate of EDPII. This is clearly seen in a plot of dihydrostreptomycin uptake rate against $\Delta \psi$ (Fig. 2). Threshold values for dihydrostreptomycin uptake in $B$. subtilis have been reported and shown to vary depending on dihydrostreptomycin as well as $\mathrm{K}^{+}$concentration (Bryan \& $\mathrm{Kwan}$, 1983). At a concentration of $25 \mu \mathrm{g}$ dihydrostreptomycin $\mathrm{ml}^{-1}$ and $3 \mathrm{mM}-\mathrm{K}^{+}$a threshold $\Delta \psi$ of $-119 \mathrm{mV}$ was found. Since we determined $\Delta \psi$ at a dihydrostreptomycin concentration of $5 \mu \mathrm{g} \mathrm{ml}^{-1}$ and in the presence of $0.8 \mathrm{mM}-\mathrm{K}^{+}$the values are consistent with each other. 
Table 1. Effect of various inhibitors on the membrane potential $(\Delta \psi)$ in B. subtilis.

$\Delta \psi$ was determined from $\left[{ }^{3} \mathrm{H}\right\} \mathrm{TPMP}+$ measurements as described in Methods.

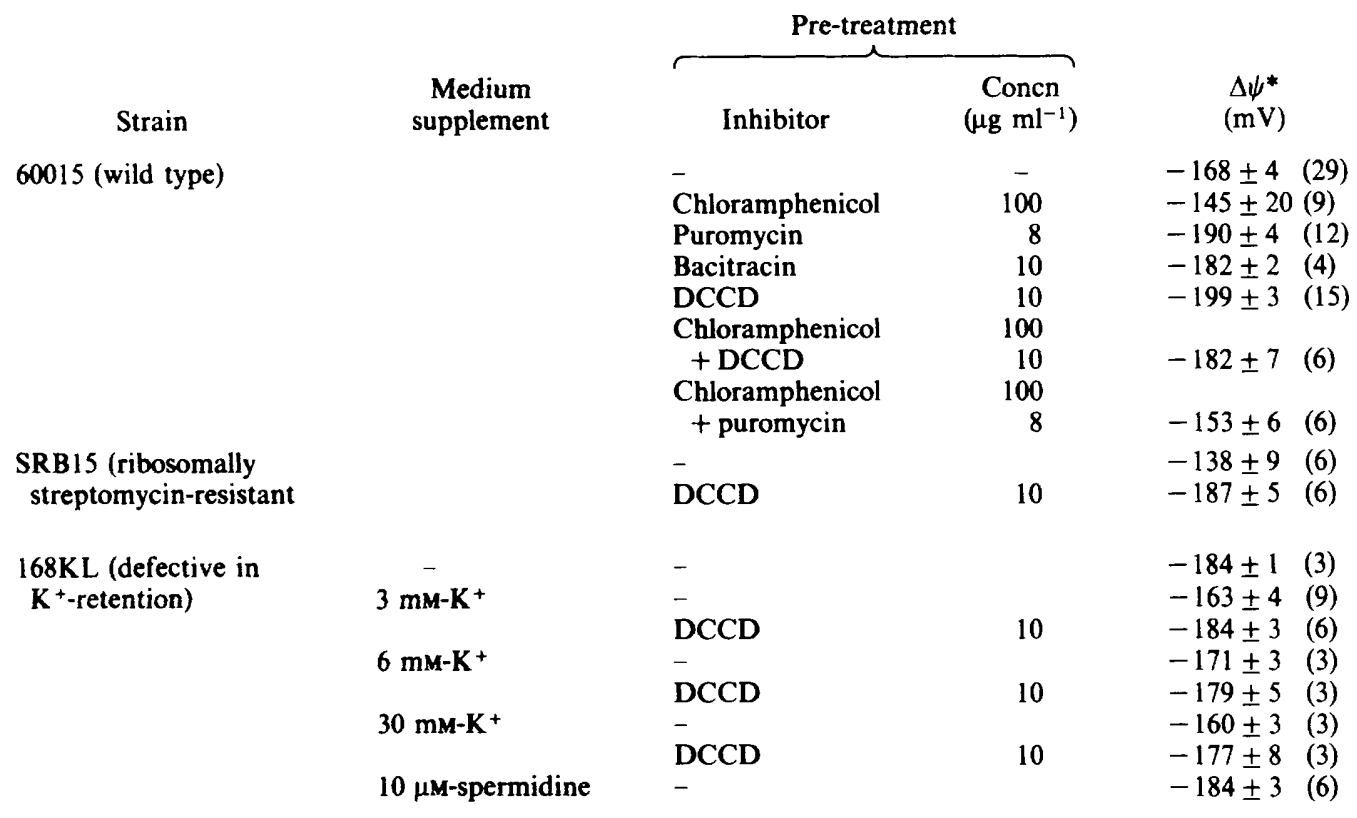

* Mean value $\pm \mathrm{SD}$; no. of determinations in parentheses.

Interestingly, the reduction in the magnitude of $\Delta \psi$ caused by pre-incubation in the presence of chloramphenicol was overcome by DCCD but not by puromycin (Table 1), although in neither case was the obligate threshold value reached.

Dihydrostreptomycin and polyamine uptake in the ribosomally streptomycin-resistant mutant B. subtilis $S R B 15$

Autostimulation of dihydrostreptomycin uptake does not take place in ribosomally streptomycin-resistant strains, although other miscoding aminoglycosides do enhance dihydrostreptomycin uptake in such mutants (Höltje, 1979). This was confirmed for $B$. subtilis SRB15 (Fig. 3). Besides kanamycin and gentamicin puromycin and DCCD also stimulated dihydrostreptomycin uptake (Fig. 3) by increasing the magnitude of $\Delta \psi$ (shown for DCCD in Table 1). Generally, dihydrostreptomycin accumulation in this mutant was lower than in the wild-type. This parallels the finding that the magnitude of the standard $\Delta \psi$ as well as the elevated potential provoked by DCCD pre-incubation is lower in B. subtilis SRB15.

A ribosomally streptomycin-resistant mutant offers the opportunity of measuring dihydrostreptomycin uptake under conditions where the miscoding effect of dihydrostreptomycin and its resulting autostimulation of uptake is eliminated. Under these conditions, the trivalent cation spermidine is taken up by DCCD-stimulated mutant cells to the same extent as dihydrostreptomycin when added in equimolar concentrations (Fig. 4), indicating a non-specific electrogenic transport of these polycations. Because the $\mathrm{p} K^{\prime}$ of the secondary amine group of dihydrostreptomycin is about 7.6 and the $\mathrm{pH}$ of the assay medium is 7.2 , dihydrostreptomycin is likely to be taken up in its trivalent cation form.

Dihydrostreptomycin uptake in the $\mathrm{K}^{+}$-retention mutant $B$. subtilis $168 \mathrm{KL}$

Cations and monovalent ions (in particular $\mathrm{K}^{+}$) antagonize uptake and killing of bacteria by aminoglycoside antibiotics (Campbell \& Kadner, 1980; Hancock, 1981). On the other hand, the first measurable alteration in the physiology of the target cell caused by dihydrostreptomycin is 


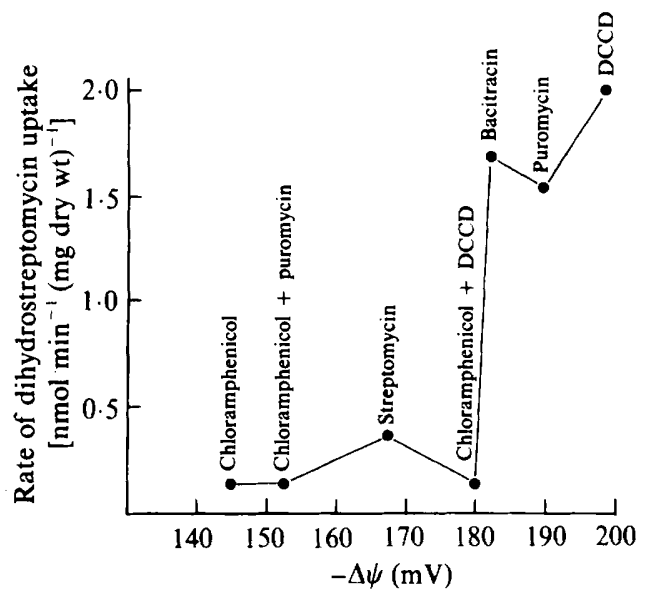

Fig. 2. Dependence of the rate of dihydrostreptomycin uptake on $\Delta \psi$. Different values of $\Delta \psi$ were obtained by pre-treatment of $B$. subtilis 60015 as indicated (see Fig. 1 and Methods). [ ${ }^{3} \mathrm{H}$ ]Dihydrostreptomycin uptake was measured over a 3 min time interval.

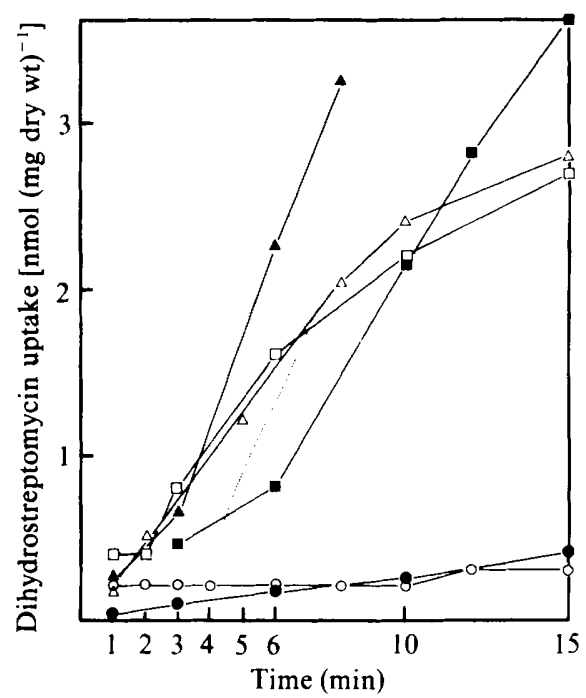

Fig. 3

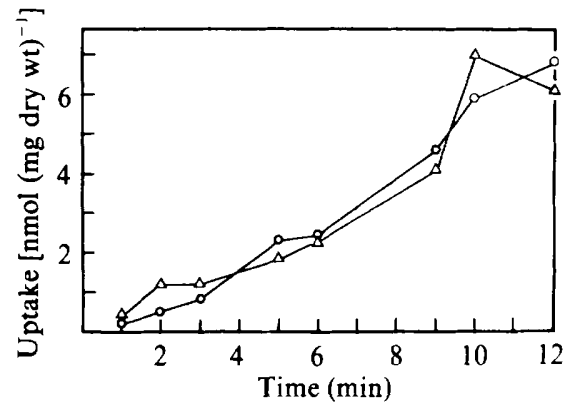

Fig. 4

Fig. 3. Uptake of dihydrostreptomycin by the ribosomally streptomycin-resistant mutant $B$. subtilis SRB15. Cells were grown in complex medium at $37^{\circ} \mathrm{C}$ to an $\mathrm{OD}_{578}$ of about 0.2 and pre-incubated for $5 \mathrm{~min}$ in the presence of $5 \mu \mathrm{g} \mathrm{ml}^{-1}$ of streptomycin $(O)$, gentamicin $(\square)$ or kanamycin $(\triangle)$, or in the presence of $8 \mu \mathrm{g}$ puromycin $\mathrm{ml}^{-1}(\square)$ or in the presence of $10 \mu \mathrm{g} \mathrm{DCCD} \mathrm{m} \mathbf{l}^{-1}(\triangle)$ before addition of $\left[{ }^{3} \mathrm{H}\right.$ ]dihydrostreptomycin $\left(5 \mu \mathrm{g} \mathrm{ml}^{-1} ; 37 \mathrm{kBq} \mathrm{ml}^{-1}\right)$; one batch served as a control $(\mathrm{O})$. Samples were withdrawn as indicated and dihydrostreptomycin accumulation was determined as described in Methods.

Fig. 4. Comparison of spermidine and dihydrostreptomycin uptake by DCCD-stimulated $B$. subtilis SRB15. Cells were grown at $37^{\circ} \mathrm{C}$ in complex medium to an $\mathrm{OD}_{578}$ of about 0.2 and incubated for $3 \mathrm{~min}$ in the presence of $10 \mu \mathrm{g} \mathrm{DCCD} \mathrm{ml} \mathrm{m}^{-1}$. The culture was divided into two subcultures: to one $6.6 \mu \mathrm{M}$ $\left[{ }^{3} \mathrm{H}\right]$ dihydrostreptomycin $\left(37 \mathrm{kBq} \mathrm{ml}{ }^{-1}\right)$ was added $(\mathrm{O})$; to the second $6.6 \mu \mathrm{M}-\left[{ }^{14} \mathrm{C}\right]$ spermidine $(4.625 \mathrm{kBq})(\triangle)$ was added. Samples were withdrawn at the indicated times and the accumulation of spermidine or dihydrostreptomycin was determined as described in Methods. 


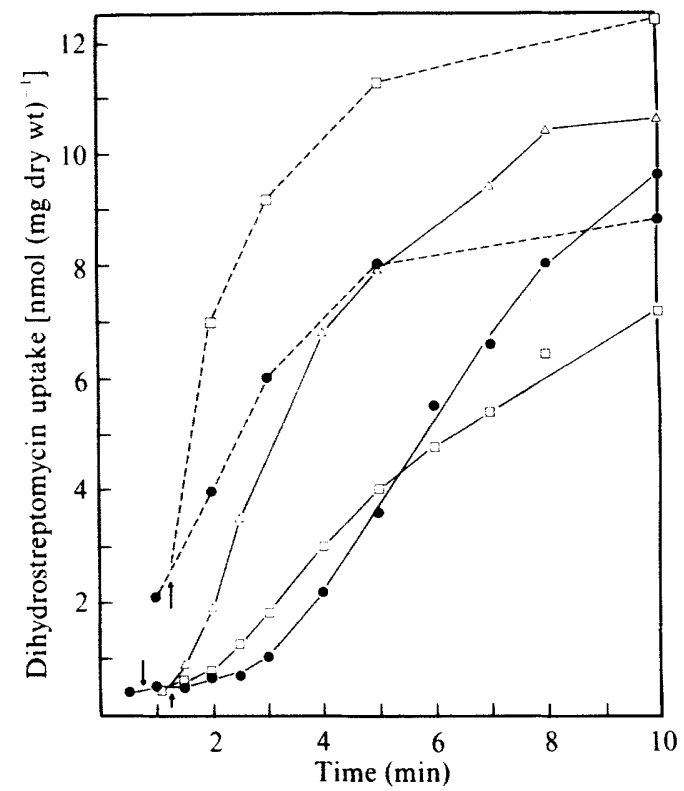

Fig. 5. Effect of valinomycin on uptake of dihydrostreptomycin by $B$. subtilis 60015 . Cells were grown in complex medium at $37^{\circ} \mathrm{C}$ to an $\mathrm{OD}_{578}$ of about $0 \cdot 2$. The culture was divided into two subcultures: one was pre-incubated for $3 \mathrm{~min}$ in the presence of $10 \mu \mathrm{g} \mathrm{DCCD} \mathrm{ml}{ }^{-1}(---)$ before addition of $\left[{ }^{3} \mathrm{H}\right] \mathrm{di}$ hydrostreptomycin $\left(5 \mu \mathrm{g} \mathrm{ml}^{-1} ; 37 \mathrm{kBq} \mathrm{ml}^{-1}\right)$ to both subcultures. Valinomycin $\left(5 \mu \mathrm{g} \mathrm{ml}^{-1}\right)$ was added (arrowed) at $0.75 \mathrm{~min}(\triangle)$ or $1.25 \mathrm{~min}(\square)$ after initiation of dihydrostreptomycin uptake; one batch received no valinomycin and served as a control (O). Dihydrostreptomycin accumulation was determined as described in Methods.

an efflux of $\mathrm{K}^{+}$(Dubin et al., 1963), which coincides with the onset of the stimulated phase of dihydrostreptomycin uptake. In the light of $\Delta \psi$ being the driving force for aminoglycoside accumulation it is a reasonable assumption that efflux of $\mathrm{K}^{+}$increases $(-\Delta \psi)$ and thereby stimulates dihydrostreptomycin uptake (EDPII). It was, therefore, of interest to study the effect of the $\mathrm{K}^{+}$-specific ionophore valinomycin on dihydrostreptomycin uptake.

Valinomycin, when added very early during the course of autostimulation, i.e. in the EDPI uptake phase, greatly enhanced uptake (Fig. 5) whereas when given during the second phase of uptake (EDPII) it inhibited dihydrostreptomycin uptake (not shown). Also, for cells which had been pre-treated with DCCD ('stimulated for uptake') a defined time period was found in which further stimulation of dihydrostreptomycin uptake by valinomycin could be achieved (Fig. 5).

Unfortunately, unlike in $E$. coli, only one $\mathrm{K}^{+}$-transport mutant of $B$. subtilis has been described so far. This mutant (B. subtilis $168 \mathrm{KL})$ shows normal $\mathrm{K}^{+}$uptake but is unable to retain and accumulate $\mathrm{K}^{+}$(Willis \& Ennis, 1968). For normal growth sufficient $\mathrm{K}^{+}$has to be supplied with the medium. In Tryptone broth containing $0.8 \mathrm{mM}-\mathrm{K}^{+}$the mutant grew slowly; uptake of dihydrostreptomycin was quite poor and no autostimulation took place (Fig. 6), although a $\Delta \psi$ value of $-183 \mathrm{mV}$ (Table 1) was determined. Addition of increasing amounts of $\mathrm{K}^{+}$to the growth medium (which stimulated growth only slightly) increased overall streptomycin accumulation but amplified the stimulatory effect on the rate of uptake caused by pre-treatment of the cells with DCCD (Fig. 6).

An even more dramatic enhancement of dihydrostreptomycin uptake in the $\mathrm{K}^{+}$-retention mutant was observed in the presence of a $10 \mu \mathrm{M}$ concentration of the polyamines putrescine or spermidine, known to stabilize ribosomes and thus stimulate misreading induced by dihydrostreptomycin (Goldemberg \& Algranati, 1981). It should be noted that the polyamines, unlike DCCD, did not increase $(-\Delta \psi)$ but obviously enabled the cells to be autostimulated by dihydrostreptomycin as indicated by the biphasic character of dihydrostreptomycin accumulation (Fig. 7). 


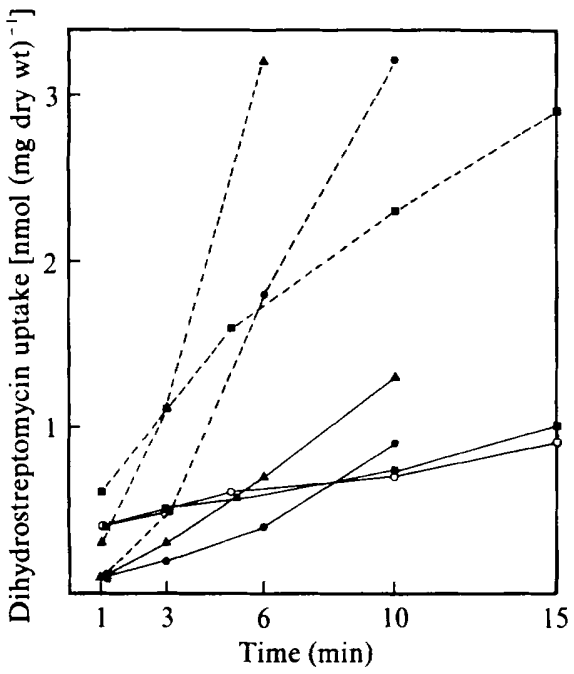

Fig. 6

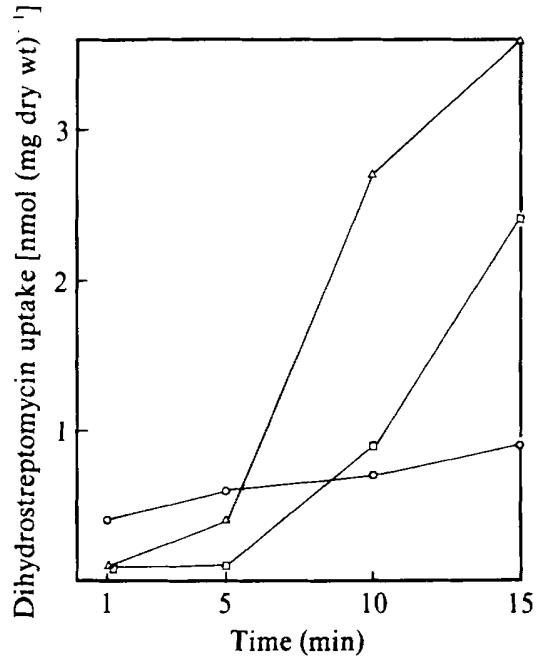

Fig. 7

Fig. 6. Effect of $\mathrm{K}^{+}$on the uptake of dihydrostreptomycin by the $\mathrm{K}^{+}$-retention mutant $B$. subtilis $168 \mathrm{KL}$. Cells were grown in complex medium at $37^{\circ} \mathrm{C}$ in the presence of $0.8 \mathrm{mM}(\mathrm{O}), 3 \mathrm{mM}(\square), 6 \mathrm{mM}$ $(\Delta)$ or $30 \mathrm{~mm}(\mathbf{O}) \mathrm{K}^{+}$. Each culture was divided into two and one of each pair of subcultures was preincubated for $3 \mathrm{~min}$ in the presence of $10 \mu \mathrm{g} \mathrm{DCCD} \mathrm{ml}^{-1}(----)$ before addition of $\left[{ }^{3} \mathrm{H}\right]$ dihydrostreptomycin $\left(5 \mu \mathrm{g} \mathrm{ml}^{-1} ; 37 \mathrm{kBq} \mathrm{ml}^{-1}\right)$. Samples were taken as indicated and treated as described in Methods.

Fig. 7. Effect of polyamines on the uptake of dihydrostreptomycin by the $\mathrm{K}^{+}$-retention mutant $B$. subtilis $168 \mathrm{KL}$. Cells were grown in complex medium at $37^{\circ} \mathrm{C}$ in the presence of either $10 \mu \mathrm{M}$ spermidine $(\triangle)$ or $10 \mu \mathrm{M}$-putrescine $(\square)$, or without any addition $(O)$. Uptake of $\left[{ }^{3} \mathrm{H}\right]$ dihydrostreptomycin $\left(5 \mu \mathrm{g} \mathrm{ml}^{-1} ; 37 \mathrm{kBq} \mathrm{m}{ }^{-1}\right)$ was determined as described in Methods.

\section{DISCUSSION}

The driving force of the energy-dependent accumulation of the aminoglycoside antibiotic dihydrostreptomycin is the electrical component, the $\Delta \psi$, of the protonmotive force, $\Delta p$, which is defined as $\Delta p=(\Delta \psi-2 \cdot 3 R T / F) / \Delta \mathrm{pH}$ (Arrow \& Taber, 1986; Damper \& Epstein, 1981). This we confirmed and extended for the enhancement of dihydrostreptomycin uptake in $B$. subtilis by agents as diverse as bacitracin (inhibits murein synthesis), puromycin (inhibits protein synthesis) and DCCD (inhibits the membrane-bound $\mathrm{H}^{+}$-ATPase). The common effect of all three compounds was shown to be an increase in $(-\Delta \psi)$. We could estimate a threshold value for $\Delta \psi$ (under the experimental conditions about -180 to $-190 \mathrm{mV}$ ) that was required in order to establish a high rate of uptake (EDPII).

We showed that $\Delta \psi$ not only drives uptake of the polycationic dihydrostreptomycin but also the accumulation of polycations like putrescine and spermidine. In the streptomycin-resistant mutant $B$. subtilis SRB15 $\left[{ }^{14} \mathrm{C}\right]$ spermidine was accumulated at the same rate and extent as $\left[{ }^{3} \mathrm{H}\right]$ dihydrostreptomycin after raising $(-\Delta \psi)$ by pre-incubation with DCCD. Similarly, it has been reported that increasing the magnitude of $\Delta \psi$ by pre-incubation with puromycin in a ribosomally resistant mutant (rpsL) of $E$. coli increased the uptake of polyamines and arginine (Bryan \& Kwan, 1983). Thus, by raising $(-\Delta \psi)$ above a certain threshold the uptake of polycations is stimulated. An earlier suggestion, however, that dihydrostreptomycin may enter the cell via an inducible polyamine uptake system, which was thought to be induced by the specific interaction of streptomycin itself with protein synthesis (Höltje, 1978), can be ruled out on the basis of several experimental results. Firstly, no indication of the appearance of a new transport protein together with enhancement of uptake could be obtained (Ahmad et al., 1980). Secondly, a non-parallel response of polyamine and dihydrostreptomycin uptake has been demonstrated with streptomycin-transport mutants (Bryan et al., 1980; Campbell \& Kadner, 
1980) and, after starvation of the cells, for polyamines (Campbell \& Kadner, 1980). Mutual competitive inhibition of the uptake of dihydrostreptomycin and polyamines is easily explained by depolarization of the membrane (decreasing the magnitude of $\Delta \psi$ ) by both classes of polycationic compounds that seem to be taken up by electrogenic transport (Damper \& Epstein, 1981). The carriers involved have not yet been identified but a strong dependence on a functional electron transport system indicates that a component of the electron transport chain may be involved directly in the uptake process. Whereas ubiquinones have been proposed to be responsible for gentamicin and dihydrostreptomycin uptake in E. coli (Bryan \& K wan, 1983), a requirement for cytochrome $a a_{3}$, besides an adequate $\Delta \psi$, has been demonstrated for the uptake of dihydrostreptomycin in B. subtilis (Arrow \& Taber, 1986). High rates of cell growth (i.e. high rate of protein synthesis) are necessary for stimulated uptake of dihydrostreptomycin (Muir et al., 1984, 1985).

Dependence of the second phase of energy-dependent uptake (EDPII) on protein synthesis, which was taken as an indication of the induction of an additional transport system (Höltje, 1978), is shown here to be the result of a specific interference of dihydrostreptomycin itself with protein synthesis that ultimately increases the magnitude of $\Delta \psi$. Polyamines as well as dihydrostreptomycin merely respond non-specifically to the increase in $(-\Delta \psi)$. The question to be answered is: how is the magnitude of $\Delta \psi$ increased by the interaction of streptomycin with ongoing protein synthesis?

The peculiar phenomenon of autostimulation of dihydrostreptomycin accumulation depends on codon misreading, since all miscoding aminoglycoside antibiotics similarly stimulate dihydrostreptomycin uptake, whereas kasugamycin and spectinomycin, which do not cause miscoding, are ineffective (Höltje, 1978). In contrast to the aminoglycosides most inhibitors of protein synthesis impair dihydrostreptomycin accumulation (Hancock, 1981). However, puromycin, within certain concentrations, stimulates uptake by increasing $(-\Delta \psi)$ as shown here. By analogy to dihydrostreptomycin the stimulatory effect of puromycin depends on a specific interaction with protein synthesis (Hurwitz et al., 1981). Indeed, miscoding aminoglycosides and puromycin have a common effect on protein synthesis, namely to cause non-functional proteins to accumulate (Davies $e t$ al., 1964). In the case of puromycin peptidyl puromycin fragments are released from the ribosomes (Pestka, 1971). In contrast to Davis et al. (1986), who proposed that the interference with normal protein synthesis by streptomycin or puromycin results in the incorporation of faulty proteins into the membrane which form non-specific membrane channels, we would like to emphasize another common consequence of the action of these antibiotics. The abnormal proteins synthesized are rapidly degraded by proteases (Goldberg, 1972; Hewitt \& Kogut, 1977) at a rate that increases exponentially with time (Kogut $\&$ Carrier, 1980). This causes an osmotic problem for the bacterium by the sudden increase in the intracellular concentration of small peptides and amino acids. The cell would be expected to respond to this change by a net efflux of $\mathrm{K}^{+}$, which is known to be one of the most important mechanisms by which bacteria adapt to changes in the osmotic pressure (Epstein \& Schultz, 1965). Indeed, efflux of $\mathrm{K}^{+}$has been described as one of the first effects of dihydrostreptomycin (Dubin et al., 1963). Efflux of cations, however, would increase the magnitude of $\Delta \psi$. As shown in this report $(-\Delta \psi)$ does increase in the presence of puromycin and, very probably, is also increased by the action of dihydrostreptomycin during autostimulation.

Our interpretation directly contradicts the attractive model presented by Bryan \& Kwan (1983) to explain the various steps in the complex pathway from first binding, followed by uptake into the cell, to finally killing of the bacterial cell by aminoglycoside antibiotics. In this model the onset of aminoglycoside uptake with increased rate (EDPII) by autostimulation is neither paralleled nor triggered by an increase of $(-\Delta \psi)$; rather, binding of the aminoglycoside to ribosomes that are part of polysomes is claimed to initiate perturbation of the ribosomal cycle and thereby disturb the integrity of the cytoplasmic membrane. This part of the model is based on the experimental finding of a decrease in tetraphenylphosphonium ion accumulation in $E$. coli caused by gentamicin, which, in our opinion, must not be taken as evidence for a decrease of the membrane potential because of the depolarizing effect of the trivalent gentamicin cation. In addition the $\mathrm{K}^{+}$efflux that coincides with the onset of increased dihydrostreptomycin uptake 
(EDPII) must contribute to an increase in the magnitude of $\Delta \psi$ (inside negative). The second set of experiments to determine $\Delta \psi$ during autostimulation, reported by Bryan \& Kwan (1983), suffer from the fact that before addition of the lipophilic probe the cells had been centrifuged and washed to remove the aminoglycoside. We found that centrifugation and resuspension in fresh medium severely affected the transport activity of the cells. This has also been reported for Bacillus licheniformis (MacLeod et al., 1973). Furthermore, the dramatic increase in the rate of uptake during the establishment of the EDPII can hardly be explained by increased binding to polysomes. The exponential increase of proteolysis (Kogut \& Carrier, 1980), however, may very well explain the stimulation of uptake by a factor as high as $1000-$ fold. Also, toluene treatment of cells from EDPII released most of their accumulated dihydrostreptomycin, indicating that this portion is probably in a free form and not bound to ribosomal structures.

Besides DCCD, which increases $(-\Delta \psi)$ at the expense of $\Delta \mathrm{pH}$ by blocking the influx of protons via the ATPase, a major return route for protons, it was shown that valinomycin and bacitracin can also stimulate dihydrostreptomycin uptake. Valinomycin renders the cytoplasmic membrane specifically permeable to $\mathrm{K}^{+}$, stimulating influx or efflux depending on the difference in concentration between the inside and outside of the cell and on the existing $\Delta \psi$ (Shioi et al., 1980). Added during EPDI it stimulated dihydrostreptomycin uptake, whereas applied later it impaired uptake, possibly due to the fact that the depolarizing effect of valinomycin became predominant. Bacitracin, which was shown here for the first time to enhance dihydrostreptomycin uptake, may similarly function as an effector of $\mathrm{K}^{+}$fluxes. Bacitracin, which inhibits murein synthesis by binding to the lipid carrier undecaprenyl pyrophosphate, surprisingly also has an effect on protoplasts of $B$. megaterium: this has been shown to be due to an efflux of $\mathrm{K}^{+}$caused by bacitracin (Hancock \& Fitz-James, 1964). It can be concluded that, in general, changes in the fluxes of cations are likely to affect the uptake of aminoglycoside antibiotics and thereby their therapeutic efficacy.

\section{REFERENCES}

Ahmad, M. H., ReChenmaCher, A. \& BöCK, A. (1980). Interaction between aminoglycoside uptake and ribosomal resistance mutations. Antimicrobial Agents and Chemotherapy 18, 798-806.

Anand, N., Davis, B. D. \& Armitage, A. K. (1960). Uptake of streptomycin by Escherichia coli. Nature, London 185, 23-24.

ArRow, A. S. \& TABer, H. W. (1986). Streptomycin accumulation by Bacillus subtilis requires both a membrane potential and cytochrome $a a_{3}$. Antimicrobial Agents and Chemotherapy 29, 141-146.

Bryan, L. E. \& KwaN, S. (1983). Roles of ribosomal binding, membrane potential, and electron transport in bacterial uptake of streptomycin and gentamicin. Antimicrobial Agents and Chemotherapy 23, 835-845.

Bryan, L. E. \& VAN DEN Elzen, H. M. (1976). Streptomycin accumulation in susceptible and resistant strains of Escherichia coli and Pseudomonas aeruginosa. Antimicrobial Agents and Chemotherapy 9 , 928-938.

Bryan, L. E. \& Van den Elzen, H. M. (1977). Effects of membrane-energy mutations and cations on dihydrostreptomycin and gentamicin accumulation by bacteria: a model for entry of streptomycin and gentamicin in susceptible and resistant bacteria. Antimicrobial Agents and Chemotherapy 12, 163-177.

Bryan, L. E., Haraphongse, R. \& Van den Elzen, H. M. (1976). Gentamicin resistance in clinical isolates of Pseudomonas aeruginosa associated with diminished gentamicin accumulation and no detectable enzymatic modification. Journal of Antibiotics 29, 743-753.
Bryan, L. E., Kowand, S. K. \& Van den Elzen, H. M. (1979). Mechanism of aminoglycoside antibiotic resistance in anaerobic bacteria: Clostridium perfringens and Bacteroides fragilis. Antimicrobial Agents and Chemotherapy 15, 7-13.

Bryan, L. E., Nicas, T., Holloway, B. W. \& Crowther, C. (1980). Aminoglycoside-resistant mutation of Pseudomonas aeruginosa defective in cytochrome $c_{552}$ and nitrate reductase. Antimicrobial Agents and Chemotherapy 17, 71-79.

Camprell, B. D. \& KadNer, R. J. (1980). Relation of aerobiosis and ionic strength to the uptake of dihydrostreptomycin in Escherichia coli. Biochimica et biophysica acta 593, 1-10.

DAMPER, P. D. \& EPSTEIN, W. (1981). Role of the membrane potential in bacterial resistance to aminoglycoside antibiotics. Antimicrobial Agents and Chemotherapy 20, 803-808.

Davies, J., GilberT, W. \& Gorini, L. (1964). Streptomycin, suppression, and the code. Proceedings of the National Academy of Sciences of the United States of America 51, 883-887.

Davis, B. D., Chen, L. \& TAI, P. C. (1986). Misread protein creates membrane channels: an essential step in the bactericidal action of aminoglycosides. Proceedings of the National Academy of Sciences of the United States of America 81, 6164-6168.

Dubin, D. T., HANCOCK, R. \& DAvis, B. D. (1963). The sequence of some effects of streptomycin in Escherichia coli. Biochimica et biophysica acta 74, 476.

Eisenberg, E. S., Mandel, L. J., KabaCK, H. R. \& Miller, M. H. (1984). Quantitative association 
between electrical potential across the cytoplasmic membrane and early gentamicin uptake and killing in Staphylococcus aureus. Journal of Bacteriology 157, 863-867.

Epstein, W. \& Schultz, S. G. (1965). Cation transport in Escherichia coli. V. Regulation of cation content. Journal of General Physiology 49, 221234.

GOLDBERG, A. L. (1972). Degradation of abnormal proteins in Escherichia coli. Proceedings of the National Academy of Sciences of the United States of America 69, 422-426.

Goldemberg、 S. H. \& Algranati, I. D. (1981). Polyamine requirement for streptomycin action on protein synthesis in bacteria. European Journal of Biochemistry 117, 251-255.

HANCOCK, R. (1962). Uptake of ${ }^{14}$ C-streptomycin by some micro-organisms and its relation to their streptomycin sensitivity. Journal of General Microbiology 28, 493-501.

HaNCOCK. R. E. W. (1981). Aminoglycoside uptake and mode of action - with special reference to streptomycin and gentamicin. Journal of Antimicrobial Chemotherapy 8, 249-276.

Hancock, R. \& Fitz-James, P. C. (1964). Some differences in the action of penicillin, bacitracin and vancomycin on Bacillus megaterium. Joumal of Bacteriology 87, 1044-1050.

HEwITT, J. \& KoGUT, M. (1977). An investigation of mistranslation in vivo induced by streptomycin by an examination of susceptibility of abnormal proteins to degradation. European Journal of Biochemistry 74, 285-293.

HöltJE, J.-V. (1978). Streptomycin uptake via an inducible polyamine transport system in Escherichia coli. European Journal of Biochemistry 86, 345-351.

HöLTJE, J.-V. (1979). Induction of streptomycin uptake in resistant strains of Escherichia coli. Antimicrobial Agents and Chemotherapy 15, 177-181.

Hurwitz, C. \& Rosano, C. L. (1962). Accumulation of label from $\mathrm{C}^{14}$-streptomycin by Escherichia coli. Journal of Bacteriology 83, 1193-1201.

Hurwitz, C., Braun, C. B. \& Rosano, C. L. (1981) Role of ribosome recycling in uptake of dihydro- streptomycin by sensitive and resistant Escherichia coli. Biochimica et biophysica acta 652, 168-176.

Kogut, M. \& CARrier, M. J. (1980). A new look at the antibiotic action of streptomycin: the unitary hypothesis revisited. FEMS Microbiology Letters 9, 245253.

Macleod, R. A., Thurman, P. \& Rogers, H. J. (1973). Comparative transport activity of intact cells, membrane vesicles, and mesosomes of Bacillus licheniformis. Journal of Bacteriology 113, 329-340.

Mates, S. M., Eisenberg, E. S., Mandel, L. J., Patel, L, Kaback, H. R. \& Miller, M. H. (1982). Membrane potential and gentamicin uptake in Staphylococcus aureus. Proceedings of the National Academy of Sciences of the United States of America 79, 6693-6697.

Miller, M. H., Edberg, S. C., Mandel, L. J., Behar, C. F. \& Steigbigel, N. H. (1980). Gentamicin uptake in wild-type and aminoglycoside-resistant small-colony mutants of Staphylococcus aureus. Antimicrobial Agents and Chemotherapy 18, 722-729.

Muir, M. E., Ballesteros, M. \& Wallace, B. J. (1984). Effect of growth rate on streptomycin accumulation by Escherichia coli and Bacillus megaterium. Journal of General Microbiology 130, 20152022.

Muir, M. E., Ballesteros, M. \& Wallace, B. J. (1985). Respiration rate, growth rate and the accumulation of streptomycin in Escherichia coli. Journal of General Microbiology 131, 2573-2579.

PESTKA, S. (1971). Inhibitors of ribosome functions. Annual Review of Microbiology 25, 487-562.

Shioi, J.-I., Matsuura, S. \& Imae, Y. (1980). Quantitative measurements of proton motive force and motility in Bacillus subtilis. Journal of Bacteriology 144, 891-897.

TABER, H. \& Halfenger, G. M. (1976). Multipleaminoglycoside-resistant mutants of Bacillus subtilis deficient in accumulation of kanamycin. Antimicrobial Agents and Chemotherapy 9, 251.

WILLIS, D. B. \& ENNIS, H. L. (1968). Ribonucleic acid and protein synthesis in a mutant of Bacillus subtilis defective in potassium retention. Journal of Bacteriology 96, 2035-2042. 